Przegląd Badań Edukacyjnych

ISSN 1895-4308

nr 18 (1/2014), s. 195-204

METODY ZBIERANIA

I ANALIZY DANYCH

W BADANIACH

EDUKACYJNYCH

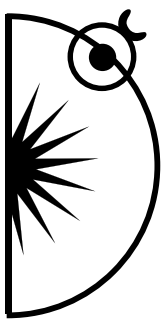

Magdalena Cuprjak

\title{
Doświadczanie codzienności ucznia. Etnografia zaangażowana
}

DOI: http://dx.doi.org/10.12775/PBE.2014.013

\section{Wprowadzenie}

Poznawanie i rozumienie ,innego" jest zadaniem trudnym i fascynującym jednocześnie. Jest procesem, którego trwanie zależy od wielu czynników, tj.: rodzaju terenu badawczego i związanych z tym trudności, stopnia złożoności sytuacji oraz rodzaju stawianych pytań. Ponadto po dwóch latach przebywania wśród młodzieży gimnazjalnej mogę powiedzieć, że ten wachlarz może poszerzyć się o jeszcze jeden ważny element, jakim jest zaangażowanie. Nie mam tu na myśli zaangażowania rozumianego jako wnikliwość czy dociekliwość badawcza, które jest wpisane w charakter metod terenowych, ale jako aktywność, będącą wyrazem troski o życie badanych, zmierzającą do refleksji (a może i rozwoju) badanych podmiotów.

Prowadzone badania, w pewnej ich części, nazywam zaangażowanymi z przynajmniej dwóch powodów. Jednym jest fakt, że sam pomysł na nie zrodził się na skutek narastającego buntu przeciwko negatywnemu obrazowi uczennic i uczniów gimnazjum, jaki prezentują polskie media, a za ich pośrednictwem reprodukuje opinia publiczna. Postanowiłam samodzielnie zweryfikować medialne doniesienia i „na własnej skórze” przekonać się, jak jest naprawdę, zdając sobie jednocześnie sprawę, że owo „naprawdę” obiektywnie nie istnieje. Drugim powodem jest wspomniane powyżej staranie się, aby wykorzystać swój potencjał i zrobić coś dla dobra badanej młodzieży. 
W niniejszym tekście chciałabym zatem przedstawić perspektywę zaangażowanej badaczki, która - mówiąc metaforycznie - zarzuciła plecak na plecy, wyposażony w notes, długopis, aparat fotograficzny oraz dyktafon i wyruszyła w podróż do niezbyt odległego, aczkolwiek mało znanego miejsca, jakim jest gimnazjum. Perspektywę uczestniczki, która była trudna, ale jednocześnie niezwykle inspirująca i ożywcza. Chciałabym pokazać również, że pomimo dużych ograniczeń czasowych, wynikających z łączenia badań z pracą na uczelni, miałam możliwość przyjrzenia się codzienności uczennic i uczniów z różnych perspektyw, uczestnicząc w lekcjach, przerwach i różnych okolicznych wydarzeniach. Prezentowane tu badania, będące częścią większego projektu dają obraz w skali mikro - jednej z klas, jedynego gimnazjum w małym, kilkunastotysięcznym mieście.

\section{Nowy paradygmat - uczestnictwo}

Wobec klasycznych, teoretycznych badań, praktykowanych w ramach podstawowych paradygmatów, tj.: pozytywistyczny, postpozytywistyczny, teorii krytycznej czy konstruktywistyczny (Guba, Lincoln 2009, s. 283) stawiany jest zarzut, że wykorzystują badane osoby w celu zdobycia informacji i pozostawiająje samym sobie - z otwartymi, dotychczas nieuświadomionymi problemami i dylematami. Badani, nawet w badaniach o charakterze jakościowym, stają się przedmiotami, z których wydobywane są dane. Dane, oddzielone od źródła, zaczynaja żyć samodzielnie, a co się dzieje z samym źródłem zazwyczaj nie jest ważne. Używając mocno przejaskrawionego cytatu: „,po nas choćby potop” (Dudkiewicz 2011, s. 6). W badaniach o charakterze jakościowym mamy do czynienia z większymi możliwościami łączenia perspektyw teoretycznych, aby dostosować proces badawczy do terenu badań. Bardzo często mówi się o wrażliwości, a nawet empatii badacza, ale nadal chodzi tu głównie o zgromadzenie danych.

Po drugiej stronie są badania praktyczne, które zawsze mają na celu zmianę, poprawę sytuacji osoby badanej. Są to badania diagnostyczne, prowadzone zarówno na gruncie psychologii, jak i pedagogiki. Ich źródłem zawsze jest problem, trudność czy choroba, a efektem ulepszenie sytuacji bądź wyleczenie pacjenta. W tym przypadku cała uwaga jest skoncentrowana na osobie diagnozowanej i nie ma możliwości, aby o niej zapomnieć. Badania te trudno jest jednak nazwać naukowymi, ponieważ nie generują teorii, ale jednostkowe rozwiązania praktyczne.

Praktyka badawcza pokazuje, że te dwie orientacje mogą spotkać się w drodze, dając nową jakość, ponieważ metodologia zmienia się tak samo, jak 
zmienia się rzeczywistość. Współczesność nazywana przez Baumana (2007, s. 7) „płynną nowoczesnością” wymaga nowych metod i perspektyw badawczych. Pojawiają się nowe pola badawcze, nowe ogniska problemów człowieka, związanych z transformacją oraz wyraźną zmianą tempa i jakości życia. Takie zagadnienia, jak np. wykluczenie społeczne, wymagają nie tylko dogłębnej eksploracji, ale przede wszystkim planowania systemowej pomocy ludziom potrzebujaccym. Proces tworzenia nowych perspektyw badawczych jest niezwykle dynamiczny, a pojawiające się publikacje i organizowane konferencje pokazują, że toczy się wokół niego dyskusja. Jednym z przykładów może być organizowane przez Profesora Dariusza Kubinowskiego III Sympozjum Metodologii Jakościowych pt.: „W poszukiwaniu dróg i inspiracji”. Sam tytuł wskazuje na istnienie potrzeby tworzenia nowych rozwiązań metodologicznych, w nowych warunkach społecznych. Organizatorzy proponują podczas sympozjum ,rozmowy o doświadczeniach $\mathrm{w}$ pokonywaniu granic poznania, przekraczaniu konwencji i sięganiu do standardów, łączeniu różnych orientacji teoretyczno-metodologicznych, problematyki i perspektyw odległych z pozoru od siebie dyscyplin, odkrywaniu dla analiz jakościowych fenomenów i zjawisk społecznych, będących wcześniej przedmiotem opisu przede wszystkim ilościowego" (http://www.tsbj.wpsnz.uz.zgora.pl/).

Grupa badaczy zachodnich już w latach czterdziestych XX wieku wypracowała nowy rodzaj badań, opartych na współpracy z podmiotami badania, co w 1996 roku zaowocowało poszerzeniem czterech podstawowych paradygmatów o piąty tzw. uczestniczący/ oparty na współpracy (za: Guba, Lincoln 2009, s. 290). Piąty paradygmat dopuszcza pierwszeństwo praktycznego poznawania, poprzez wspólne działanie prowadzące do zmiany świata. Kładzie nacisk na wspólne doświadczanie osób badanych i prowadzących badanie, nazywając badanych współbadaczami. Można powiedzieć, że „,role są tu wymienne - poznawany jest także poznającym", a ponadto osobie prowadzącej badania przypisuje się „kompetencje emocjonalne, demokratyczną osobowość i aktywne zaangażowanie w daną rzeczywistość" (Sławecki 2012, s. 81).

W ostatnich latach również naukowcy w Polsce, z takich dyscyplin naukowych, jak socjologia czy pedagogika zadają sobie pytania o perspektywę badań zaangażowanych $\mathrm{w}$ zmianę (m. in. autorzy Badania $w$ działaniu - nowy paradygmat, 2011). Z podejmowanych tematów i dyskusji wynika, że z jednej strony widzą potrzebę stawania po stronie ludzi słabszych, pokrzywdzonych, czy wykluczonych, aby swoimi działaniami wspomagać ich emancypację, a z drugiej wciąż obawiają się o naukowy obiektywizm i rzetelność takich badań. Pomimo długiej tradycji badań w działaniu w Stanach Zjednoczonych, dylematy 
związane z ich akceptacją przez środowiska naukowe nadal są aktualne (m.in. Foley, Valenzuela 2009, s. 322).

Nurt badań edukacyjnych, uprawianych na gruncie piątego paradygmatu jest w Polce stosunkowo młody. Rozpowszechniony został dzięki publikacji $\mathrm{H}$. Cervinkowej i B. D. Gołębniak pt.: Badania w działaniu. Pedagogika i antropologia zaangażowane (2010), w której został zawarty zbiór tekstów źródłowych, stanowiących ugruntowanie teoretyczne tej perspektywy badawczej. Autorki książki na wstępie piszą o renesansie badań w działaniu oraz ich kluczowym znaczeniu w przyszłości badań jakościowych, w związku z pogłębiającym się kryzysem normatywności (ibidem, s. VII).

\section{Od codzienności do etnografii zaangażowanej}

Podjęte przeze mnie badania etnograficzne trudno jest jednoznacznie zakwalifikować do jednego paradygmatu. Niewątpliwie kierunek działań wyznacza paradygmat konstruktywistyczny z perspektywą interpretatywną, ze względu na interpretację symboli kultury szkolnej, zachowania uczniów oraz potrzebę skonstruowania możliwie pełnego obrazu ucznia, na podstawie wielu źródeł informacji przy zastosowania wielu metod zbierania danych. Cały projekt badań realizowany był w jednej ze szkół gimnazjalnych i obejmował 8 klas różnych szczebli edukacji. Jednakże od początku zaangażowałam się w życie jednej klasy, przyglądając się ich codzienności szkolnej przez ponad 2 lata i ta część badań osadzona jest w paradygmacie działaniowym.

Klasyczna etnografia, wpisująca się w paradygmat teorii krytycznej czy konstruktywistyczny jest schematem badawczym, którego celem jest badanie określonej społeczności w jej naturalnym środowisku, w naturalnym kontekście kulturowym. Według Angrosino (2010, s. 44) „etnografia jest sztuką i nauką skupioną na opisie grupy ludzkiej - jej instytucji, zachowań interpersonalnych, wytworów materialnych i przekonań", natomiast działania etnografa skupione są na rutynowym, codziennym życiu badanych społeczności. Kategoria codzienności staje się zatem bardzo ważna, a nawet kluczowa, ponieważ tylko dzięki uczestnictwu w rutynowych czynnościach mamy możliwość poznania nie tylko pełnego repertuaru zachowań, ale także ich źródeł.

Głównym celem tak rozumianej etnografii jest opis, a działanie etnografa to wnikliwa obserwacja. Jeśli jednak do obserwacji dołączy uczestnictwo, mające na celu wywołanie zmiany, wtedy wykracza się poza klasyczny wymiar etnografii i tworzy nową jakość - etnografię zaangażowaną (Rys. 1). 


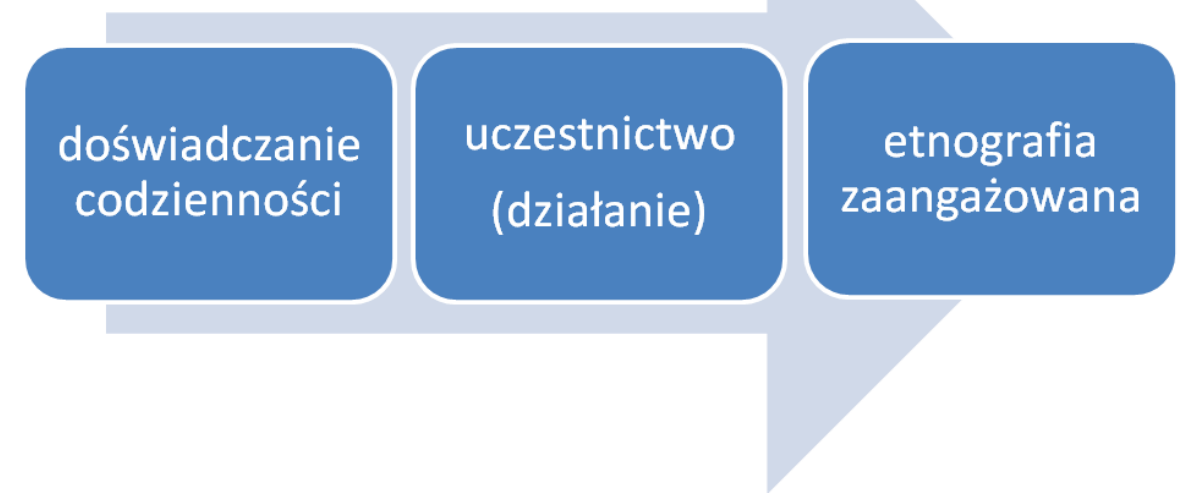

Rys. 1. Proces etnografii zaangażowanej

W ramach tak pojmowanego schematu badawczego wykorzystane zostały przeze mnie następujące metody i techniki zbierania danych:

1. obserwacja uczestnicząca (etnograficzna),

2. metody projekcyjne,

3. metody/zabawy integracyjne,

4. wywiady (z uczniami, nauczycielami),

5. przeszukiwanie źródeł wtórnych.

Każda z zastosowanych metod daje inny obraz uczennicy i ucznia gimnazjum. Zgromadzony materiał empiryczny można interpretować indywidualnie, ponieważ każda z metod pozwala na wydobywanie adekwatnych dla niej informacji i w oparciu o nie formułowanie wniosków. W moich badaniach potraktowałam je komplementarnie, tworząc swoistą mozaikę - jeden, niejednorodny obraz, a ponadto dobierałam je stosownie do postępów obserwacji oraz potrzeb badanej młodzieży.

\section{Etnografia zaangażowana w praktyce}

Badania w gimnazjum rozpoczęłam od obserwacji i codziennych rozmów z uczniami podczas przerw. Obserwacja była pierwszą i przez całe badanie podstawową metodą zbierania danych, dzięki której nie tylko gromadziłam dane, ale również wszelkie wydarzenia mogłam na bieżąco umieszczać w kontekście. 
Każdy jej etap był ważny - od pierwszych doświadczeń, udziału w lekcjach i swobodnych rozmów, po kolejne, bardziej wnikliwe obserwacje zdarzeń krytycznych np. podczas nocowania w szkole ${ }^{1}$. Moja rola obserwatorki zmieniała się wraz ze zdobywaniem nowych informacji oraz wzajemnego oswajania się z uczniami. Nowe informacje poszerzały zakres pól problemowych wartych eksploracji, a to z kolei wymagało wprowadzenia kolejnych metod badawczych.

Następnym krokiem była metoda projekcyjna. Na jednej z lekcji godziny wychowawczej, przy obecności wychowawczyni, młodzież została losowo przydzielona do 5 grup. Każda grupa otrzymała materiały papiernicze z poleceniem: „Narysuj gimnazjalistkę/ gimnazjalistę oraz uczennicę/ ucznia szkoły podstawowej”. Pomimo początkowej niechęci do zadania, prawie wszyscy uczniowie zaczęli prace, aczkolwiek atmosfera, tempo i zaangażowanie były zróżnicowane. Podczas wykonywania przez uczniów tego zadania miałam możliwość obserwacji sposobów komunikacji, zasad współpracy, a nawet kształtowania się hierarchii na pozycjach liderów i ,szeregowych” wśród członków poszczególnych zespołów. Poza obserwacją uczniów, swoją uwagę skupiłam również na nauczycielce. Jej obecność mogła oczywiście wpływać na ekspresję uczniów, aczkolwiek nie zauważyłam niepokojących symptomów skrępowania. Dla mnie ta obecność była cenna, ze względu na możliwość obserwowania reakcji na postępy prac.

Metoda projekcyjna, stosowana głównie w badaniach psychologicznych, daje również duże możliwości poznawcze w badaniach pedagogicznych. Za jej pomoca, można bowiem dotrzeć do nieuświadomionych przeżyć i pokładów wiedzy, które nie mają możliwości ujawnienia się w „refleksyjnym doświadczeniu" (M. Straś-Romanowska 2003, s. 38). Stworzone przez uczniów prace dają możliwości poznania sytuacji ucznia gimnazjum, ze względu na rekonstrukcję „,systemu ukrytych znaczeń podmiotu w ich wzajemnych powiązaniach i w ich powiązaniu z całościową, względnie trwałą sytuacją życiową osoby lub z aktualnym układem bodźców, które oddziałują na jednostkę" (ibidem, s. 39). Bodźce działające na badanych uczniów można odczytać już po wstępnej ocenie rysunków, a zweryfikować za pomocą przeprowadzonej dyskusji grupowej, skoncentrowanej na wytworzonych pracach, będącej uzupełnieniem metody projekcyjnej. Ponadto narracja klasy, jaka powstała podczas dyskusji, pozwo-

${ }^{1}$ Uczniowie spędzają całą noc w szkole; grając w piłkę w sali gimnastycznej, oglądając wspólnie filmy, czy nawet bawiąc się w berka po szkolnych korytarzach, mają szansę na poznanie siebie, integrację klasy, ale również oswojenie się z budynkiem szkoły, który nie jest już tylko miejscem do nauki, ale również zabawy. 
liła na uchwycenie kolejnej perspektywy funkcjonowania uczniów: jako grupy - wspólnoty oraz jako grupy - zbioru indywidualności.

Analizy rysunków uczniów utworzyły pewien obraz gimnazjalistki i gimnazjalisty, ale równocześnie zrodziły kolejne pytania, przede wszystkim o możliwości interpretacyjne zastosowanej metody. Powstaje bowiem wątpliwość, czy powstałe prace przedstawiały rzeczywistego ucznia tej klasy, czy reprodukowały zasłyszane opinie. Na pewno na ich podstawie można zbadać rodzaj bodźców, jakie docierają do uczniów, a to już daje wiele możliwości analitycznych. W celu dalszego poznania badanych uczniów i uczennic sięgnęłam po proste techniki integracyjne, tj.: „Co czuję”, „Jestem - potrafię - mam” oraz „Mąciciele” (Tomkiewicz-Bętkowska, Czubak 2011). Moje działania ${ }^{2}$ były jednocześnie kontynuacją pracy podjętej przez wychowawczynię klasy, której celem było motywowanie swoich podopiecznych do pracy nad sobą, refleksji oraz lepszych osiągnięć. Ja również zakładałam, że dzięki zastosowanym technikom integracyjnym zdobędę nową wiedzę o uczniach klasy, ale przede wszystkim uczniowie dowiedzą się więcej o samych sobie.

Najbardziej widoczny efekt został osiągnięty w zabawie „Mąciciele”, która polega na tym, że uczniowie za pomocą stopni na schodach rangują 14 wymienionych zachowań: od najmniej (pierwszy stopień) do najbardziej szkodliwych (ostatni stopień). Głównym celem tej techniki jest „nauka zachowań akceptowanych społecznie; oraz nabycie umiejętności rozróżniania i nazywania określonych cech i zachowań" (ibidem, s. 109). Po pracy indywidualnej nastąpiła dyskusja w grupach, a później na forum całej klasy. Cenną informacją dla mnie było to, czy uczniowie potrafią definiować zachowania nieakceptowane społecznie, np. za pomocą przykładów koleżanek i kolegów z bliskiego otoczenia oraz czy chętnie dyskutują $\mathrm{w}$ grupach o wszystkich typach zachowań i czy ich narracja jest spójna.

Kolejną, a po obserwacji najważniejszą metodą był wywiad indywidualny skoncentrowany na informacjach (Rubacha 2008, s. 146). Spotkania odbywały się w bibliotece szkolnej lub w klasie, a zatem w warunkach naturalnych dla uczniów. Wywiady miały charakter swobodnej rozmowy, czasami przyjmując formę dyskusji. To kolejna nowa perspektywa, dzięki której mogłam poznać indywidualny wymiar funkcjonowania każdej z osób badanych. Poza oczywistą wartością, jaką są wypowiedzi, poddawane osobnej, wnikli-

${ }^{2}$ Podczas dwóch spotkań towarzyszyło mi dwoje studentów z Sekcji Badawczej Koła Naukowego Pedagogów, działającego na Wydziale Nauk Pedagogicznych Uniwersytetu Mikołaja Kopernika w Toruniu: Paulina Kazaniecka i Marcin Szostakowski. 
wej analizie, bardzo istotny był sam fakt spotkania twarzą w twarz i możliwość weryfikacji moich spostrzeżeń dotyczących danej osoby. Sytuacja wywiadu nie należała już do codziennych i uczniowie reagowali na nią w różnorodny sposób - od swobody, po skrępowanie i trudną do pokonania blokadę. Nowe okoliczności dawały mi informację o podatności danej osoby na wpływy grupy, ponieważ nagle lider pozostawał bez audytorium i jego zachowanie ulegało zmianie. Zadawane przeze mnie pytania oscylowały wokół definicji uczennicy i ucznia gimnazjum w kilku perspektywach: ogólnie - jako inni gimnazjaliści/ gimnazjalistki, personalnie - ja gimnazjalista/ gimnazjalistka oraz zewnętrznie - jak nas widzą inni spoza gimnazjum. Interesujące były różnice w optyce dziewcząt i chłopców, wynikające, jak wstępnie mogę ocenić, $\mathrm{z}$ etapu rozwojowego, a tym samym $\mathrm{z}$ różnego wartościowania tych samych doświadczeń.

Uzupełnieniem wszystkich zastosowanych metod było przeszukiwanie źródeł w tórnych, które polegało na badaniu budynku szkoły, miejsc spotkań uczniów podczas przerw, informacji w gablotach na korytarzu i w klasie. Przedmiotem przeszukiwania był również sposób ubierania się uczniów w badanej klasie, co wynikało z potrzeby porównania wyglądu ucznia gimnazjum prezentowanego przez uczniów podczas wywiadów, ale przede wszystkim obecnego w opinii społecznej (przekazywaną przez prasę, telewizję oraz Internet), a tym obserwowanym w różnych sytuacjach szkolnych.

\section{Podsumowanie}

Wszystkie materiały zgromadzone podczas prowadzenia badań są poddawane szczegółowej analizie i zostaną zaprezentowane w kolejnym artykule. Każdy element stanowi wartość samą w sobie i jednocześnie jest częścią jednego obrazu. Zaprezentowane tu badania można porównać z innymi perspektywami badawczymi, tj.: podejście mozaikowe A. Clark (Zwiernik 2012, s. 162) czy etnografia krytyczna (Foley, Valenzuela 2009). Pierwsza skoncentrowana jest jednak głównie na badaniu małych dzieci, stawianych w roli przewodników po swoim świecie emocji i organizacji, np. placówki wychowawczej. Druga natomiast związana jest z głębokimi zmianami w sferze społeczno-politycznej. Moja perspektywa mogłaby wpisać się w zakres etnografii krytycznej, gdyby zaangażowanie przyjęło głębszą formę, zmierzającą do zmian, np. w systemie szkoły. Takie badania wymagają dobrego przygotowania całego zespołu badawczego, w skład którego wchodziliby m.in. przedstawiciele szkoły, poradni psychologiczno-pedagogicznej, a także rodzice i uczniowie. Moje badania są 
małym krokiem, który za Kurtem Lewinem mogłabym nazwać „rozmrożeniem problemu". Kolejne kroki to kolejne etapy, które mam nadzieję nastąpią.

Takie podejście nie jest jednak wolne od trudności czy niedoskonałości. Samo zaangażowanie, definiowane jako ,postawa osoby, która jest przekonana o słuszności tego, co robi” (www.wsjp.pl), związane jest z wartościowaniem, co może utrudniać obiektywizm i zniekształcać obraz badanej rzeczywistości. Bliski kontakt z badanymi tworzy wzajemną więź, w efekcie czego łatwo usprawiedliwiać pewne zachowania. Ponadto sam proces badania jest mniej rygorystyczny, płynne są ramy czasowe i merytoryczne, co może powodować utratę kontroli nad tym, co jest badane albo prowadzić do „swoistego nihilizmu i pokusy łatwego uzasadniania każdej decyzji metodologicznej" (Dudkiewicz 2011, s. 6). Podczas prowadzenia badań nie można zapomnieć o rzetelności osoby badającej, jak i wszystkich podejmowanych przez nią działań.

Tym tekstem chciałabym zwrócić uwagę na takie sytuacje badawcze, w których rola badacza opisującego otaczająca go rzeczywistość może poszerzyć się o tzw. czynnik ludzki, polegający na zaangażowaniu się w życie badanych osób. Wiąże się to z przekroczeniem paradygmatu pozytywistycznego, a (cytując): „kiedy etnograf porzuci pozytywistyczne złudzenie, że techniki badawcze mogą stworzyć bezstronny, obiektywny punkt widzenia, ignorowanie bardziej intuicyjnych lub subiektywnych sposobów poznawania traci sens" (Foley, Valenzuela 2009, s. 316). Ponadto uważam, że ta perspektywa nie powinna rodzić dylematów związanych z jej (nie)naukowością, zwłaszcza w obliczu poszerzenia się listy podstawowych paradygmatów naukowych. Wyrażam nadzieję, że zaplecze metodologiczne jest na tyle pojemne, że pomieści wiele orientacji badawczych. Poza tym badania nazywane akademickimi mają mocną pozycję ,ma rynku badań" i ich status nie jest zagrożony. Nie chodzi zresztą o deprecjonowanie ich wartości, ale o przychylność środowisk naukowych wobec badań aktywizujących, zwłaszcza na gruncie pedagogiki, dyscypliny, która z gruntu jest wartościująca i lepiej powinna radzić sobie z dylematem zaangażowania.

\section{Literatura}

Angrosino M. (2010) Badania etnograficzne i obserwacyjne, Wydawnictwo Naukowe PWN: Warszawa.

Bauman Z. (2007), Plynne czasy. Życie w epoce niepewności, Wydawnictwo Sic!: Warszawa. Cervinkowa H., Gołębniak B. D. (2010), Badania w działaniu. Pedagogika i antropologia zaangażowane, Wydawnictwo Naukowe DSW: Wrocław. 
Dudkiewicz M. (2011), Metodologiczny kontekst badań aktywizujacych, „Animacja Życia Publicznego. Zeszyty Centrum Badań Społeczności i Polityk Lokalnych”, nr 2 (5), s. 4-6.

Foley D., Valenzuela A. (2009), Etnografia krytyczna. Polityka wspótpracy, w: N. K. Denzin, Y. Lincoln (red.), Metody badawcze w naukach społecznych (s. 315-339), Wydawnictwo Naukowe PWN: Warszawa.

Guba E. G., Lincoln Y. (2009), Kontrowersje wokót paradygmatów, sprzeczności i wytaniajace się zbieżności, w: N. K. Denzin, Y. Lincoln (red.), Metody badawcze w naukach społecznych (s. 281-313), Wydawnictwo Naukowe PWN: Warszawa.

Rubacha K. (2008), Metodologia badań nad edukacja, Wydawnictwa Akademickie i Profesjonalne: Warszawa.

Sławecki B. (2012), Znaczenie paradygmatów w badaniach jakościowych, w: D. Jemielniak (red.), Badania jakościowe. Podejścia i teorie (s. 57-87), Wydawnictwo Naukowe PWN: Warszawa.

Straś-Romanowska M. (2003), Status metody projekcyjnej jako metody jakościowej, w: M. Łaguna, B. Lachowska (red.), Rysunek projekcyjny jako metoda badań psychologicznych (s. 31-40), Towarzystwo Naukowe KUL: Lublin.

Tomkiewicz-Bętkowska A., Czubak J. (2011), Zgrana klasa Ja - Ty - My, Oficyna Wydawnicza „Impuls”: Kraków.

Zwiernik J. (2012). Podejście mozaikowe w badaniu doświadczania przez dzieci życia codziennego w instytucjach wczesnej opieki i edukacji, „Przegląd Badań Edukacyjnych” nr 15 (2), s. 159-176.

www.wsjp.pl (data dostępu: 10.04.2014 r.)

\section{Experiencing everyday school-life of student. Ethnography of involved}

\section{Summary}

This article presents the practical application ethnography of involved in the research of middle school students. Ethnography of involved was established in the new paradigm: participating, which allows priority to practical learning through joint action leading to changes in the situation of the respondents. The text presents carried out the research process using methods and techniques within the general framework of this research perspective.

Keywords: ethnography of involved, participating paradigm, research methods, middle school. 